\title{
PROFILE OF POLYA'S PROBLEM-SOLVING ABILITIES MODEL AMONG SENIOR HIGH SCHOOL STUDENTS: LESSON FROM STOICHIOMETRIC CLASS
}

\author{
Herunata*, Nur Kholilah \\ Department of Chemistry, Faculty of Mathematics and Natural Sciences, Universitas Negeri Malang \\ Jl. Semarang No. 5 Malang, Indonesia
}

\begin{abstract}
Based on several studies, it is known that there are students' difficulties in applying problem-solving as a problem-solving method, especially in stoichiometric material. Because solving stoichiometric' problems requires not only algorithmic skills but also a good understanding of chemical concepts. This study uses subjective test questions to determine the steps or methods students use to solve problem-solving test questions. The results showed that the students' problem-solving ability in the upper group was very high, the middle group was quite high. In contrast, the lower group was classified as low with mastery of Polya steps, respectively $85 \%, 68 \%$, and $36 \%$. There is a significant correlation between students' mastery of problem-solving steps. The correlation of mastery of problem-solving steps for students in the upper group was 0.786 (high), the middle group was 0.883 (very high), and the lower group had a correlation score of 0.803 (very high).
\end{abstract}

Keywords: problem-solving ability, Polya model, stoichiometry

\section{INTRODUCTION}

Chemistry is a branch of science that studies the properties, structures, changes, laws, and principles that describe these changes, concepts, and theories that interpret them [1]. Chemistry is much broader than just numbers, formulas, and abstract theories. Chemistry is a logical science filled with interesting ideas [2]. Knowledge of chemistry is distinguished from conceptual knowledge and procedural knowledge or algorithms. Thus, two understandings must be mastered to understand chemistry as a whole, namely conceptual understanding and algorithmic understanding [3].

Concept understanding is categorized as declarative knowledge and algorithmic ability as procedural ability [4]. Understanding the concept helps students build a meaningful representation of the problem at hand and limits the search for solutions by matching the schema or conditions in the problem with a series of actions in procedural memory. The most important area in learning is problem-solving [5]. In his research, Gabel revealed that most students solve chemical problems using only algorithmic methods and do not understand the basic concepts of chemistry [5]. This is because students are accustomed to using algorithmic methods in calculation problems, as Chiu points out that procedural (algorithmic) knowledge is activated more quickly than declarative (conceptual) knowledge [6].

Stoichiometry is a chemical material that contains quite complex chemical concepts and is one of the chemical materials closely related to calculations. Stoichiometry comes from the Greek stoicheion, an element or part, and metron, which means to measure. Stoichiometry is the study

\footnotetext{
*Corresponding author: Department of Chemistry, Faculty of Mathematics and Natural Sciences, Universitas Negeri Malang. Jl. Semarang No. 5 Malang, Indonesia. Email: herunata.fmipa@um.ac.id
} 
of quantitative aspects of chemical formulas and reactions and relates the mass number of substances to chemical entities consisting of (atoms, ions, molecules), or unit formula) [7]. Solving stoichiometric problems at a glance only requires algorithmic skills. Still, without a good understanding of chemical concepts, students cannot solve stoichiometric problems well and will even experience difficulties, so structured, and systematic problem-solving skills are needed.

One way to overcome the complexity of problem-solving is by identifying students' stages in problem-solving (1). This is to find out the differences in the strategies used by students who successfully solve problems with students who fail to solve problems [8]. Several domestic researchers have conducted research that aims to analyze students' steps in solving problems. If viewed from the Polya stage, previous researchers analyzed the second and third stages carried out by students, namely devising and carrying out the plan (implement the plan). Amalia analyzed the steps used by students in solving problems on stoichiometry material [9]. In his research used 20 steps in solving stoichiometry problems. Each question consists of more than one step so that each step can be analyzed where the error is. The results of the research conducted on stoichiometric material explained that the difficulty of students in solving stoichiometry problems lies in the ability to understand the concept of the basic laws of chemistry $(21 \%)$, reaction equations (25\%), the concept of $\mathrm{Ar}$ and $\mathrm{Mr}(84 \%)$, the mole concept (40\%). \%), the concept of empirical formula and the molecular formula $(30 \%)$, the concept of a mass percent $(13 \%)$, and the concept of limiting reagent $(16 \%)$.

The results of another study by Nurjannah showed that (1) the mastery of the steps for solving stoichiometry questions for the upper group students was high, and the mastery of concepts was high with a correlation value between mastery of concepts and mastery of steps of 0.625 (high unidirectional relationship), (2) mastery of the steps of solving stoichiometry questions. Middle group students are high, and concept mastery is quite high with a correlation value between concept mastery and step mastery of -0.183 (reverse relationship), (3) mastery of stoichiometric problem-solving steps for lower group students is low, and concept mastery is low with correlation value mastery of concepts with mastery of steps of 0.178 (very low unidirectional relationship) [10].

Zidny, R., et al showed the results of their research. There was a significant relationship between students' understanding of concepts on stoichiometry material and algorithmic problemsolving abilities on stoichiometric material [11]. Understanding the concepts of class X students on stoichiometric material on a) determining the equivalent, chemical reaction based on submicroscopic diagrams, some (20\%) understand the concept, $(10 \%)$ understand part of the concept, $(47 \%)$ understand partly with specific misconceptions, $(7 \%)$ misconception, $(17 \%)$ do not understand the concept; b) determination of the number of molecules of the reaction product produced at the end of the reaction based on the ratio of available reagents half $(53 \%)$ understand the concept, (13\%) understand some of the concepts. (7\%) do not understand the concept; c) determining the limiting reagent almost half (40\%) understand the concept, $(7 \%)$ do not understand the concept, $(20 \%)$ understand some concepts with specific misconceptions, $(27 \%)$ have misconceptions, $(7 \%)$ do not understand the concept [11].

Thus, problem-solving skills are important things that must be possessed by students in high school to solve problems in stoichiometry. Problem-solving is an effort made to resolve the problems found. One of the problem-solving models that are widely adopted in learning is the Polya model, in addition to the John Dewey model and the David Johnson model. Polya, a mathematician, in his book entitled "How To Solve It" suggests four problem-solving steps, namely (1) understanding the problem (understanding the problem), (2) devising a plan (composing a plan), (3) carrying out the plan (implement the plan), and (4) looking back (check back) [12]. The description of the four steps suggested by Polya, which are used as a basis in solving a problem, can be described as follows: 


\section{a. Understanding the Problem}

The first step is to read the problem and make sure that students understand it correctly. The characteristics that students understand about the content of the questions are that students can express questions and their answers as follows:

1) What data or information can be found from the questions?

2) What is the essence of the problem that requires solving?

3) Are there formulas, pictures, graphs, tables, or other special signs in the problem?

4) Are there important conditions that need to be considered in the problem?

The assessment targets at the stage of understanding the problem include:

1) Students can analyze questions. This can be seen whether the student understands and understands what is known and asked in the question.

2) Students can write down what is known and what is asked in formulas, symbols, or simple sentences.

\section{b. Devising a Plan}

At this stage, students should think about whether they have faced this problem or other similar problems. In addition, students must think about other problems related to the problem at hand. There may be a relationship that occurs. Furthermore, students must determine the appropriate strategy to solve the problem. Understanding problem-solving strategies is a method or method that is often used and successful in the problem-solving process. In preparing this plan, students can use the following strategies that might help them to be able to solve problems:

1) Guessing and checking (Intelligent Guessing and Testing)

2) Making a drawing/diagram (Make a drawing)

3) Looking for a pattern (Finding a pattern)

4) Making a systematic list (Organizing Data)

5) Moving from behind (Working Backwards)

6) Stating the problem in a simpler form (Simpler Analogous Problem)

7) Solving part by part of the problem (Finish Part of the Problem)

8) Stating the problem from a different point of view (Adopting a Different Point of View)

9) Taking into account every possibility (Accounting for All Possibilities)

10) Considering the impossible/extreme (Considering Extreme Cases)

11) Making logical reasoning (Logical Reasoning)

The assessment targets at the stage of developing a completion plan (devising a plan) include:

1) Students can look for important concepts or theories that support each other.

2) Students can determine the right steps to solve the problem.

\section{c. Carrying Out the Plan}

At this stage, students carry out a problem-solving plan based on predetermined steps by checking the truth at each step. Students perform calculations by utilizing the required data, including appropriate concepts, theories, formulas, or equations. At this stage, students begin to enter data until it leads to the solution plan that has been designed.

Implementing this plan has a higher assessment weight than the other stages. The considerations taken regarding the statement are that students carry out the calculation process with the plans they have prepared, also equipped with all kinds of data and information needed so that students can solve the problem well.

The target of the assessment at the stage of implementing the plan includes:

1) Students can use the steps correctly

2) Students are skilled in algorithms and accuracy in answering questions

\section{d. Checking Back (Looking back)}

At this stage, students must check the results obtained by critiquing the results, whether the results are following the problem. Re-check and review carefully every step of the solution it does. The assessment targets at the looking backstage include:

1) Students can make conclusions as a strong reason for the solution results. 
2) Students are able to use existing data and information to rework the problem if there is a more effective way that can be used to solve the problem.

Based on the description above, it can be seen that Polya's problem-solving model prioritizes the processes and strategies used by students in solving problems rather than just the results. Therefore, in problem-solving, it prioritizes the process, it will have a positive impact on students' understanding of the concept of the material and student's creativity in solving problems. The reasoning process of students in solving problems becomes more structured and systematic. Students not only write "known, asked, and answered", more than that, students are directed to understand the problem well, make a systematic problem-solving plan according to the concepts that must be passed, carry out structured planning steps. Finally, students must check to return the accuracy of the written answer.

\section{METHOD}

This research uses descriptive quantitative research methods. This research was conducted to determine the problem-solving ability of Polya Model students on stoichiometric material. Based on Polya's problem-solving steps, the researchers identified the level of students' problem-solving abilities towards stoichiometric problems according to the indicators to be achieved as follows:

Tabel 1. Indicator of Stoichiometry Material Problem Solving

\begin{tabular}{cll}
\hline No. & \multicolumn{1}{c}{ Indicator } & Problem Solving Indicator \\
\hline 1 & Writing the balanced equation for the reaction correctly. & Looking for patterns \\
\hline 2 & Determining the mass of the reactants & Looking for patterns and solving part by part of the problem \\
\hline 3 & $\begin{array}{l}\text { Converting the atomic mass to the number of moles and } \\
\text { determining the number of atomic particles }\end{array}$ & Making a systematic list \\
\hline 4 & $\begin{array}{l}\text { Applying the law of volume comparison and Avogadro's } \\
\text { hypothesis }\end{array}$ & Making logical reasoning \\
\hline 5 & $\begin{array}{l}\text { Proving and explaining the relationship between the Making logical reasoning and calculating every possibility } \\
\text { number of reactants that react with the number of } \\
\text { products produced }\end{array}$ \\
\hline 6 & $\begin{array}{l}\text { Determining the limiting reagent and the mass of the } \\
\text { residue/excess of a reaction }\end{array}$ \\
\hline 7 & $\begin{array}{l}\text { Determining the concentration of a substance in a Guessing, check and solving part by part of the problem } \\
\text { compound }\end{array}$ \\
\hline 8 & \begin{tabular}{l} 
Determining the molecular formula of a substance \\
\hline
\end{tabular}
\end{tabular}

The research subjects in this study were students of class XI MIPA SMA Negeri in the city of Malang as many as 67 students. Data collection was carried out with two types of data collection techniques, namely: (1) written test, (2) interview. Based on the data from the previous material test results, students were divided into three groups, namely the upper group (KA), the middle group (KT), and the lower group $(\mathrm{KB})$. Of the 67 students who were the research sample, $33 \%$ or 23 students were categorized as the upper group, $33 \%$ or 22 students were categorized as the lower group, and the rest or 22 students were categorized as the middle group. The division of students into the upper, middle and lower groups aims to provide a detailed explanation regarding the understanding of the concept and the location of each student's difficulties with the stoichiometry material. The instrument used in this study was a problem-solving description test, which consisted of 8 questions. The results of the instrument validation are: content validity of $96 \%$, with high validity criteria; item validity in the range $0.600-0.799$, with high validity criteria; the reliability of the question is 0.876 , with very high criteria. Students' problem-solving ability on stoichiometric material is measured by calculating the percentage of mastery of Polya's steps. Calculations are carried out with the following formula.

$$
\begin{aligned}
& \mathrm{P}_{\mathrm{n}}=\frac{\sum \mathrm{X}}{\operatorname{Sm} \mathrm{x}} \times 100 \\
& \mathrm{P}_{\mathrm{n}} \quad=\text { percentage of mastery completion step " } \mathrm{n} \text { " } \\
& \sum \mathrm{X} \quad=\text { total score obtained by students in step " } \mathrm{n} " \\
& \mathrm{Sm} \quad=\text { question maximum score } \\
& \mathrm{N} \quad=\text { number of participants }
\end{aligned}
$$


The criteria used to determine the behaviour of problem-solving abilities in the Polya Model were measured by a rating scale. The rating scale measurement scale interprets quantitative data into qualitative data [15]. The criteria used are presented in Table 2.

Table 2. Polya Model Problem Solving Ability Criteria

\begin{tabular}{ll}
\hline Percentage $(\%)$ & Validity \\
\hline $80.1-100$ & Very high \\
$50.1-80.0$ & High \\
$40.1-50.0$ & Enough \\
$20.1-40.0$ & Low \\
$0.0-20.0$ & Very low \\
\hline
\end{tabular}

\section{RESULTS AND DISCUSSION}

Students' problem-solving ability on stoichiometric material is measured by mastering the steps of the Polya Model. Each stage carried out by students was analyzed by comparing the percentage of students who answered well in each group to determine the level of problem-solving ability of students in solving problems in each sub-concept of stoichiometric material.

\section{a. Problem-Solving Ability in Reaction Equation Sub-concept}

In the reaction equation, questions are arranged based on indicators that students can write compound formulas and balanced reaction equations based on observations of pictures and information on the names of compounds given. Mastery of students in the upper group (KA), middle group (KT), and lower group $(\mathrm{KB})$ on the sub-concept of the reaction equation is shown by the percentage of students' correct answers in Table 3.

Table 3. Percentage of Students' Problem-Solving Ability in the Sub-Concept of Reaction Equations

\begin{tabular}{lllll}
\hline \multirow{2}{*}{ No } & Langkah-langkah Polya & \multicolumn{3}{l}{ Persentase kemampuan problem solving } \\
\cline { 3 - 5 } & $\begin{array}{l}\text { Memahami masalah } \\
\text { (Understanding the problem) }\end{array}$ & $89 \%$ & $79 \%$ & $63 \%$ \\
\hline $\begin{array}{l}\text { Menyusun rencana penyelesaian } \\
\text { (Devising a plan) }\end{array}$ & $97 \%$ & $86 \%$ & $59 \%$ \\
\hline $\begin{array}{l}\text { Melaksanakan rencana } \\
\text { (Carrying out the plan) }\end{array}$ & $98 \%$ & $82 \%$ & $32 \%$ \\
\hline $\begin{array}{l}\text { Memeriksa kembali } \\
\text { (Looking back) }\end{array}$ & $83 \%$ & $77 \%$ & $14 \%$ \\
\hline Rata-rata & $92 \%$ & $81 \%$ & $41 \%$ \\
\hline Kriteria Kemampuan Problem Solving & $\begin{array}{l}\text { Sangat } \\
\text { tinggi }\end{array}$ & $\begin{array}{l}\text { Sangat } \\
\text { tinggi }\end{array}$ & $\mathrm{Cukup}$ \\
\hline
\end{tabular}

Based on these data, it can be seen that the level of problem-solving ability of upper and middle group students is very high. The lower group mostly did not understand the concept of the reaction equation well. In planning and implementing the plan, they did not pay attention to the coefficient of the reaction equation, and only $14 \%$ of students checked the results of the answers. The following is a complete description of the test results and interview analysis.

From the results of tests and interviews, it is known that most of the students in the upper group understand well the concept of reaction equations. Students understand the writing of reactants and products and also understand their equivalence. The reactants are propane gas and oxygen, which have the chemical formulas $\mathrm{C}_{3} \mathrm{H}_{8}$ and $\mathrm{O}_{2}$, respectively, and the resulting products are carbon dioxide and water, which have the chemical formulas $\mathrm{CO}_{2}$ and $\mathrm{H}_{2} \mathrm{O}$, respectively. In planning and implementing the plan, students write down the steps and carry out the plan correctly; they understand that the reaction equation must be balanced by paying attention to the number of reactant and product coefficients in the equation. Balancing the reaction must be done because the coefficient is the ratio of the number of molecules involved. To find out the truth of the answer, some students checked the number of moles on the left and right sides of the reaction; if the number was the same, they concluded that their answer was correct. 
It can be said that the middle and lower groups have lower problem-solving abilities than the upper groups. Some of the shortcomings of the middle group students are the steps of making plans and carrying out plans. A small number of students write down the steps and make reaction equations without giving coefficients. They know that the reaction equation must be balanced by paying attention to the number of reactant and product coefficients in the equation. Still, They do not understand that coefficient is a ratio of quantities of the molecules involved in the reaction. They understand the coefficients in the reaction equation are used to balance the amounts of the left-hand and right-hand sides of the elements in the reaction. And also, most of the students did not re-check the answers, so they did not know the truth of the answers. The same thing happened to students in the lower group with a larger percentage.

\section{b. Problem-Solving Ability on the Mole Sub Concept in Calculation of the Quantity of Reagents and Reaction Products}

In the mole sub-concept problem in calculating the quantity of reactants and reaction products, the questions are designed so that students can change the submicroscopic representation of the molecules involved in the breakdown of glucose into a symbolic form, namely the reaction equation, calculate the number of moles of glucose needed in the reaction, calculate the number of moles of carbon dioxide produced, and convert in mass units, namely grams. The mastery of students in the upper group (KA), the middle group (KT), and the lower group $(\mathrm{KB})$ towards the sub-concept of calculating the number of reagents and reaction products is shown by the percentage of students' correct answer data in Table 4.

Table 4. Percentage of Student's Problem-Solving Ability in the Sub Concept of Mol in Calculation of the Quantity of Reagents and Reaction Products

\begin{tabular}{lllll}
\hline \multirow{2}{*}{$\begin{array}{l}\text { No. } \\
\text { Soal }\end{array}$} & Langkah-langkah Polya & \multicolumn{2}{l}{ Persentase kemampuan problem solving } \\
\cline { 3 - 4 } & $\begin{array}{l}\text { Memahami masalah } \\
\text { (Understanding the problem) }\end{array}$ & $80 \%$ & $74 \%$ & KB \\
\cline { 2 - 4 } & $\begin{array}{l}\text { Menyusun rencana penyelesaian } \\
\text { (Devising a plan) }\end{array}$ & $88 \%$ & $68 \%$ & $54 \%$ \\
\cline { 2 - 4 } & $\begin{array}{l}\text { Melaksanakan rencana } \\
\text { (Carrying out the plan) }\end{array}$ & $92 \%$ & $71 \%$ & $50 \%$ \\
\hline $\begin{array}{l}\text { Memeriksa kembali } \\
\text { (Looking back) }\end{array}$ & $67 \%$ & $39 \%$ & $42 \%$ \\
\hline Rata-rata & $82 \%$ & $63 \%$ & $41 \%$ \\
\hline Kriteria Kemampuan Problem Solving & $\begin{array}{l}\text { Sangat } \\
\text { tinggi }\end{array}$ & Tinggi & Cukup \\
\hline
\end{tabular}

Based on these data, it can be seen that the level of problem-solving ability of upper group students is very high. They are very good at understanding problems, making plans, implementing plans, and reexamining the answers to the mole concept in calculating the number of reactants and reaction products. The middle group is classified as high, but only a small part re-examines their answers. The lower group is classified as sufficient because most of them do not understand the concept well, in the steps of planning and implementing the plans of the lower group students are not systematic, some problem-solving steps are not carried out such as making reaction equations based on the submicroscopic pictures given by the questions. The following is a complete description of the test results and interview analysis.

Based on the results of tests and interviews, it is known that most of the students in the upper group understand well the concept of moles in calculating the quantity of reactants and reaction products. Students can understand the problem well, and most can change the submicroscopic representation into a symbolic representation of the given glucose decomposition reaction. At the stage of preparing the plan, the students were very good, but in carrying out the plan, some students did not pay attention to the units in performing calculations. They considered the molar mass equal to $\mathrm{Ar} / \mathrm{Mr}$ so that when doing the conversion, an error occurred. A small number of students in the upper group are also sometimes not careful in doing additions and calculations, and they do not carefully re-examine the results obtained.

In the middle and lower groups, some do not understand the concept of mole in calculating the quantity of reactants and reaction products as a whole. Students do not understand the problem well. They cannot translate the submicroscopic representation into a symbolic representation of the given glucose decomposition reaction. As stated by Bodner \& Domin that in solving chemistry problems, students must 
be able to go through the visualization process or translate representations into other forms that allow them to make conclusions efficiently [14]. In this problem, students must translate the submicroscopic form of the glucose decomposition reaction into its symbolic form, namely the glucose decomposition reaction equation. In the planning step, some of them go through the step of writing the reaction equation so that at the stage of implementing the plan, students fail to solve the problem. Another error in this step is that students assume the moles of carbon dioxide are the same as moles of glucose. Some students also do not pay attention to units in doing calculations. They assume the molar mass is the same as Ar/Mr. Students who re-examined their answers and realized that their answers were incorrect would correct their answers, but most ignored this step.

\section{c. Problem-Solving Ability on the Sub Concept of Mole and Avogadro's Constant}

Students can convert the atomic mass of Sulfur (S) with the number of moles and then determine the number of atomic particles is an indicator of the sub-concept of moles and Avogadro's constant. The mastery of the upper group (KA), middle group (KT), and lower group (KB) towards the mole sub-concept and Avogadro's constant is shown by the percentage of students' correct answer data in Table 5.

Table 5. Percentage of Students' Problem-Solving Ability on the Sub Concept of Mole and Avogadro's

\begin{tabular}{lllll}
\hline $\begin{array}{l}\text { No. } \\
\text { Soal }\end{array}$ & Langkah-langkah Polya & \multicolumn{3}{l}{ Persentase kemampuan problem solving } \\
\cline { 3 - 5 } 3. & $\begin{array}{l}\text { Memahami masalah } \\
\text { (Understanding the problem) }\end{array}$ & $79 \%$ & $60 \%$ & KB \\
\cline { 2 - 4 } & $\begin{array}{l}\text { Menyusun rencana penyelesaian } \\
\text { (Devising a plan) }\end{array}$ & $89 \%$ & $70 \%$ & $54 \%$ \\
\cline { 2 - 5 } $\begin{array}{l}\text { Melaksanakan rencana } \\
\text { (Carrying out the plan) }\end{array}$ & $100 \%$ & $76 \%$ & $39 \%$ \\
\hline $\begin{array}{l}\text { Memeriksa kembali } \\
\text { (Looking back) }\end{array}$ & $100 \%$ & $39 \%$ & $34 \%$ \\
\hline Rata-rata & $92 \%$ & $61 \%$ & $37 \%$ \\
\hline Kriteria Kemampuan Problem Solving & $\begin{array}{l}\text { Sangat } \\
\text { tinggi }\end{array}$ & Tinggi & Rendah \\
\hline
\end{tabular}

Based on these data, it can be seen that the level of problem-solving ability of students in the subconcept of the mole and Avogadro's constant for the upper group is very high. The middle group is classified as high; they are quite good at understanding problems, making plans, implementing plans. Some middle group students who solve problems unsystematically and do not re-check answers end up with wrong answers. The lower group is classified as low because most do not understand the concept well, the plans prepared by students are mostly incorrect so that when working on the answers produced are not correct, the problem-solving step that many students miss is counting the number of atomic particles by multiplying the number of moles by a number. Avogadro and only a few students checked the answers. The full description is presented in the section below.

Based on the results of interviews with students in the upper group, most of them understand well the concept of moles and Avogadro's constant. Students are able to understand the problem well, most of the upper group students are able to plan steps to solve problems systematically, and their algorithmic mastery is also very good so that in carrying out the plans, students are successful in solving problems. They understand that for every mole of atoms or molecules, there are $6.022 \times 10^{23}$ particles. Therefore, they convert the mass of sulfur into moles by dividing the mass by the molar mass and then multiplying the number of moles by Avogadro's number. To double-check the answer is very easy if, for every mole of sulfur, the number of particles is $6.022 \times 10^{23}$, then with half the number of moles ( 0.5 moles), the number of particles will be half of $6.022 \times 10^{23}$, i.e. $0.5 \times 6.022 \times 10^{23}=3.011 \times 10^{23}$ atom.

The same interview was conducted with middle and lower group students, the results showed that some of them understood the mole concept and Avogadro's constant well, but some did not understand it well. Of the total middle group students, $39 \%$ and $67 \%$ of students could not solve problems well, either from understanding the problem, making planning solutions, implementing plans, or checking answers. Some students directly multiply the mass of sulfur by Avogadro's number; besides that, another mistake made by some students is only counting the number of moles without counting the number of atomic particles. They assume that the number of particles equals the number of moles. 


\section{d. Problem Solving Ability in Sub-Concept of the Basic Laws of Chemistry}

Sub-concepts of the basic laws of chemistry are related to student mastery. Students can determine the volume of carbon dioxide gas and water vapour in the methane combustion reaction measured at the same temperature and pressure by applying the law of volume comparison and Avogadro's hypothesis. The calculation results for the upper group (KA), the middle group (KT), and the lower group (KB) are shown by the data on the percentage of students' correct answers in Table 6 .

Table 6. Percentage of Students' Problem Solving Ability in Sub-Concepts of Basic Laws of Chemistry

\begin{tabular}{lllll}
\hline \multirow{2}{*}{$\begin{array}{l}\text { No. } \\
\text { Soal }\end{array}$} & Langkah-langkah Polya & \multicolumn{3}{l}{ Persentase kemampuan problem solving } \\
\cline { 2 - 5 } 4. & $\begin{array}{l}\text { Memahami masalah } \\
\text { (Understanding the problem) }\end{array}$ & $867 \%$ & $81 \%$ & $66 \%$ \\
\cline { 2 - 5 } & $\begin{array}{l}\text { Menyusun rencana penyelesaian } \\
\text { (Devising a plan) }\end{array}$ & $98 \%$ & $84 \%$ & $45 \%$ \\
\cline { 2 - 5 } $\begin{array}{l}\text { Melaksanakan rencana } \\
\text { (Carrying out the plan) }\end{array}$ & $96 \%$ & $79 \%$ & $27 \%$ \\
\hline $\begin{array}{l}\text { Memeriksa kembali } \\
\text { (Looking back) }\end{array}$ & $83 \%$ & $79 \%$ & $26 \%$ \\
\hline Rata-rata & $91 \%$ & $81 \%$ & $41 \%$ \\
\hline Kriteria Kemampuan Problem Solving & $\begin{array}{l}\text { Sangat } \\
\text { tinggi }\end{array}$ & Sangat tinggi & Cukup \\
\hline
\end{tabular}

Based on these data, it can be seen that the level of problem-solving ability of upper and middle group students is very high. While the lower group is classified as low because most of them do not understand the concept of the law of volume comparison and Avogadro's hypothesis well, even though the sound of the law has been mentioned in the problem, the students do not understand the meaning of the law, so the plans drawn up by students are mostly incorrect so that in the when working on the answers produced are not correct, and only a few students check the results of the answers.

Based on the results of tests and interviews, students in the upper and middle groups showed that most of the students in these two groups understood the basic law of chemistry, namely the law of volume ratio. The upper group students understand that the ratio of the volume of reactant gas and reaction product is a comparison of the coefficients of substances in the gas reaction equation provided that the volume is measured at the same temperature and pressure. The volume of one mole of a substance measured under standard conditions or often called STP (temperature $0 \mathrm{oC}$ and pressure $1 \mathrm{~atm}$ ) is $22.4 \mathrm{~L}$. However, suppose the volume is measured under certain conditions. In that case, it is calculated by the general gas equation $\mathrm{PV}=\mathrm{n} \mathrm{R}$ T. Implementing the plan from the steps compiled by students can be observed that the algorithmic ability of the upper group students is very high, students are able to make conclusions that strengthen answers to problem-solving. Students can understand the problem well and solve the problem according to the steps arranged systematically.

Most of the lower group students do not understand the concept of the basic law of chemistry, namely the law of volume ratio. Students do not understand the steps that should be used to develop plans because they do not understand the concept well. Most students write answers by multiplying or dividing the known numbers in the problem. When asked during the interview, it turned out that they did not understand the meaning of Avogadro's hypothesis.

\section{e. Problem-Solving Ability in Limiting Reagent Sub Concept}

In this sub-concept, students' abilities are measured through questions number 5 and 6 below. Problem number 5 is related to indicators. Students can prove and explain the relationship between the number of reactants and the amount of product produced by calculating the number of $\mathrm{MgCl}_{2}$ products in the reaction of magnesium metal with the hydrochloric acid solution. While number 6, Students can determine the reactant that acts as the limiting reagent and calculate the mass of the remaining/excessive substance in the reaction of chlorine with fluorine which produces chlorine trifluoride through submicroscopic images and then prove it through calculations. The mastery of the students in the upper group (KA), the middle group (KT), and the lower group $(\mathrm{KB})$ is shown by the data on the percentage of students' correct answers in Table 7. 


\begin{tabular}{lllll}
\hline \multirow{2}{*}{$\begin{array}{l}\text { No. } \\
\text { Soal }\end{array}$} & Langkah-langkah Polya & \multicolumn{3}{c}{ Persentase kemampuan problem solving } \\
\cline { 2 - 4 } 5. & $\begin{array}{l}\text { Memahami masalah } \\
\text { (Understanding the problem) }\end{array}$ & $87 \%$ & $79 \%$ & $54 \%$ \\
\cline { 2 - 4 } & $\begin{array}{l}\text { Menyusun rencana penyelesaian } \\
\text { (Devising a plan) }\end{array}$ & $98 \%$ & $79 \%$ & $31 \%$ \\
\hline $\begin{array}{l}\text { Melaksanakan rencana } \\
\text { (Carrying out the plan) }\end{array}$ & $93 \%$ & $74 \%$ & $23 \%$ \\
\hline $\begin{array}{l}\text { Memeriksa kembali } \\
\text { (Looking back) }\end{array}$ & $76 \%$ & $77 \%$ & $23 \%$ \\
\hline 6. & $\begin{array}{l}\text { Memahami masalah } \\
\text { (Understanding the problem) }\end{array}$ & $75 \%$ & $58 \%$ & $42 \%$ \\
\cline { 2 - 4 } $\begin{array}{l}\text { Menyusun rencana penyelesaian } \\
\text { (Devising a plan) }\end{array}$ & $58 \%$ & $35 \%$ & $23 \%$ \\
\hline $\begin{array}{l}\text { Melaksanakan rencana } \\
\text { (Carrying out the plan) }\end{array}$ & $67 \%$ & $31 \%$ & $14 \%$ \\
\hline $\begin{array}{l}\text { Memeriksa kembali } \\
\text { (Looking back) }\end{array}$ & $54 \%$ & $34 \%$ & $14 \%$ \\
\hline Rata-rata & $76 \%$ & $58 \%$ & $28 \%$ \\
\hline Kriteria Kemampuan Problem Solving & Tinggi & Cukup & Rendah \\
\hline
\end{tabular}

Based on these data, it can be seen that the level of problem-solving ability of students in the upper group limiting reagent subconcept is quite high, and the middle group is quite sufficient. While the lower group is classified as low because most of them do not understand the concept well, the plans prepared by students are mostly incorrect, so that when working on, the answers produced are not correct. The difficulties experienced by many students include two things. First, students do not understand the concept of mole ratio before, during, and after the reaction, which is indicated by determining the initial number of moles, the number of moles reacted, and the number of moles remaining. Second, students' difficulties in mastering the steps to determine the mass of the residual substance were due to a lack of understanding of the concept of reaction equations and limiting reagents.

In detail, based on the results of interviews and answer data, most of the upper group students understand the concept of limiting reagent. Students can understand the problem very well, and this can be seen from the known data that is written and other data needed to be able to solve the problem. In addition to understanding the problems of the upper group students, they also plan to solve problems well and systematically, and it's just that in question number 6, a small number of students are only able to solve the problem partially. Some students did not answer the problem in point b because they did not understand the steps to determine the mass of the residual substance. Their representational ability is quite good. The macroscopic picture in question number 5 and the submicroscopic picture in question number 6 can be used to understand the problem better and solve the problem. Another mistake that is still often made is the lack of calculation accuracy. Students who re-check the answers well and make sure the correct results are considered successful in solving problems. However, some fill in the step-by-step column for rechecking only by copying the answers without checking the results' accuracy.

Students in the middle group understand the concept of limiting reagents. Students can understand the problem well; this can be seen from the known written data and other data needed to solve the problem. In question number 5 , some students did not write down the reaction equation. Even though the calculation of the number of moles of $\mathrm{MgCl}_{2}$ is the same as the number of moles of $\mathrm{Mg}$, conceptually, it is still not justified to assume that the moles of $\mathrm{MgCl}_{2}$ are the same as $\mathrm{Mg}$ without being proven by a balanced reaction equation. In question number 6 , most students can translate submicroscopic images to solve the problem of point a. Still, when solving the problem of point $b$, students seem to have difficulty. This is evidenced by the low percentage of planning and implementing plans. The difficulties faced by middle group students have related to Two things that cause the limiting reagent. First, students do not understand the concept of mole ratio before, during, and after the reaction, which is indicated by determining the initial number of moles, the number of moles reacted, and the number of moles remaining. Second, students' difficulties in mastering the steps to determine the mass of the residual substance were due to a lack of understanding of the concept of reaction equations and limiting reagents.

The same thing happened to the lower group with higher error intensity. Students in the lower group did not understand the concept of limiting reagents well. Students cannot understand the problem well, and this can be seen from the known data that is written and other data needed to be able to solve the 
problem. In question number 5 , some students did not write down the reaction equation, and some did not arrange the steps for solving the problem. They immediately concluded that the $\mathrm{MgCl}_{2}$ of the Rio group was not the same as the Alba group because the mass of $\mathrm{Mg}$ of the Rio group was greater without proving it by comparing the number of moles/mass of $\mathrm{MgCl}_{2}$ produced. In question number 6 , most of the students were unable to translate the submicroscopic picture, so that some of them failed to solve the problem of point a, as well as when solving the problem of point $b$, the students looked difficult, this was evidenced by the low percentage of the ability to plan and implement plans, some students even left blanks. Three things caused the difficulties experienced by middle group students regarding the limiting reagent-first, the low ability to translate macroscopic, submicroscopic, and symbolic representations. Second, students do not understand the concept of mole ratio before, during, and after the reaction, which is indicated by determining the initial number of moles, the number of moles reacted, and the number of moles remaining. Third, students' difficulty related to mastery of the step of determining the mass of the residual substance is due to the lack of understanding of the concept of the reaction equation and the limiting reagent. Most students do not understand how to re-examine the answers properly, so they do not know the truth of the answers obtained.

\section{f. Problem-Solving Ability on Sub-Concept Substance Levels}

Students can determine the content or mass of the urea compound $\left(\mathrm{CO}\left(\mathrm{NH}_{2}\right)_{2}\right)$ contained in packaged urea fertilizer following SNI, which is an indicator of the substance content sub-concept. Students' mastery of the sub-concept of substance levels is shown by the percentage of students' correct answer data in Table 8.

Table 8. Percentage of Students' Problem-Solving Ability in Sub-Concept Substance Level

\begin{tabular}{lllll}
\hline \multirow{2}{*}{$\begin{array}{l}\text { No. } \\
\text { Soal }\end{array}$} & Langkah-langkah Polya & \multicolumn{3}{l}{ Persentase kemampuan problem solving } \\
\cline { 3 - 5 } & $\begin{array}{l}\text { Memahami masalah } \\
\text { (Understanding the problem) }\end{array}$ & $81 \%$ & $74 \%$ & $\mathrm{~KB}$ \\
\cline { 2 - 4 } & $\begin{array}{l}\text { Menyusun rencana penyelesaian } \\
\text { (Devising a plan) }\end{array}$ & $77 \%$ & $73 \%$ & $72 \%$ \\
\cline { 2 - 4 } & $\begin{array}{l}\text { Melaksanakan rencana } \\
\text { (Carrying out the plan) }\end{array}$ & $93 \%$ & $54 \%$ & $51 \%$ \\
\hline $\begin{array}{l}\text { Memeriksa kembali } \\
\text { (Looking back) }\end{array}$ & $87 \%$ & $34 \%$ & $2 \%$ \\
\hline Rata-rata & $84 \%$ & $59 \%$ & $40 \%$ \\
\hline Kriteria Kemampuan Problem Solving & $\begin{array}{l}\text { Sangat } \\
\text { tinggi }\end{array}$ & Cukup & Cukup \\
\hline
\end{tabular}

The data shows that the level of problem-solving ability in the sub-concept of substance levels in the upper group is very high, while the middle and lower groups are quite adequate. The difficulty experienced by students is in understanding the problem. They assume that the entire content of urea fertilizer is a urea compound even though the details of the fertilizer content have been explained in the question. The total mass of the fertilizer packaging should be reduced by the mass of water and other compounds to determine the net mass of the urea compound contained in the fertilizer package. As a result of not understanding the problem well, the steps drawn up by students are imperfect, and implementing the plans prepared cannot solve the problem.

Based on the results of interviews, it can be seen that most of the students in the upper group understand well the concept of substance levels, namely the constituent elements of compounds. Students can understand the problem well and solve the problem according to the steps arranged systematically. The steps systematically arranged by the upper group students include three steps. First, calculate the mass of water and other compounds contained in the packaging of urea fertilizer. Second, calculate the net weight of the urea compound by subtracting the mass of packaged fertilizer with the mass of water content and other compounds. Third, calculate the elemental content of compounds $\mathrm{C}, \mathrm{H}, \mathrm{O}$, and $\mathrm{N}$ that make up the urea compound. In this third step, students must master the concept of $\mathrm{Ar}$ and Mr.. To re-check the students' answers, add up the mass of all the elements and compare it with the mass of the urea compound. The students' problem-solving ability on this question is very good; $93 \%$ of students carry out this plan very well. Only a small number of students are still not careful in the calculation process. But overall, their algorithmic skills are very good. 
Students in the middle and lower groups partially understand the concept of substance levels, namely the elements that makeup compounds. However, some of the other students could not understand the problem well. They thought that the urea fertilizer packaging contained all urea compounds, even though it was mentioned that it contained water and other compounds with a total of $1.5 \%$. The mass of water and compounds should reduce the total mass of the fertilizer packaging. Another method is to determine the net mass of urea compounds in fertilizer packaging. As a result of not understanding the problem well, the steps drawn up by students are imperfect, and implementing the plans prepared cannot solve the problem. The concept of Ar and Mr. students is quite good. They master the steps of calculating the content by comparing the element Ar and Mr. urea multiplied by the mass of the urea compound.

\section{g. Problem Solving Ability in Sub-Concepts of Empirical Formulas and Molecular Formulas}

Students' mastery of the sub-concepts of empirical formulas and molecular formulas, with indicators that students can find the molecular formula of a compound containing vitamin $\mathrm{C}$ and calculate the mass of one element of compound content, namely hydrogen in a certain amount of vitamin $\mathrm{C}$ in one package, is indicated by the percentage of students' correct answer in Table 8.

Table 8. Percentage of Students' Problem-Solving Ability in Sub-Concepts of Empirical Formulas and Molecular Formulas

\begin{tabular}{lllll}
\hline \multirow{2}{*}{$\begin{array}{l}\text { No. } \\
\text { Soal }\end{array}$} & Langkah-langkah Polya & \multicolumn{3}{l}{ Persentase kemampuan problem solving } \\
\cline { 2 - 4 } & $\begin{array}{l}\text { Memahami masalah } \\
\text { (Understanding the problem) }\end{array}$ & $87 \%$ & $81 \%$ & $\mathrm{~KB}$ \\
\cline { 2 - 4 } & $\begin{array}{l}\text { Menyusun rencana penyelesaian } \\
\text { (Devising a plan) }\end{array}$ & $98 \%$ & $84 \%$ & $49 \%$ \\
\cline { 2 - 4 } & $\begin{array}{l}\text { Melaksanakan rencana } \\
\text { (Carrying out the plan) }\end{array}$ & $96 \%$ & $79 \%$ & $26 \%$ \\
\hline $\begin{array}{l}\text { Memeriksa kembali } \\
\text { (Looking back) }\end{array}$ & $83 \%$ & $79 \%$ & $15 \%$ \\
\hline Rata-rata & $91 \%$ & $81 \%$ & $27 \%$ \\
\hline Kriteria Kemampuan Problem Solving & $\begin{array}{l}\text { Sangat } \\
\text { tinggi }\end{array}$ & Sangat tinggi & Rendah \\
\hline
\end{tabular}

The data shows that problem-solving ability in the sub-concepts of empirical formulas and molecular formulas in the upper and middle groups is very high. In contrast, the lower group is classified as low. The difficulties experienced by students are caused by the low understanding of the concept of elemental content in compounds and the concept of moles so that the ability to solve problems is low.

Based on the results of interviews and data analysis, it can be seen that most of the students in the upper and middle groups understand very well the concepts of empirical formulas and molecular formulas. Students can understand the problem well and solve the problem according to the steps arranged systematically. The steps systematically arranged by the upper group students include four steps. First, calculate the mass of the elements that make up the compound. Second, calculate the number of moles based on mass conversion and molar mass. Third, determine the empirical formula based on the ratio of each element's number of moles that make up the compound. Fourth, determine the molecular formula based on the molar mass (n) ratio and the empirical formula. Students' problem-solving ability on this matter is very good; students carry out this plan very well, only a small number of students are still not careful in the calculation process. But overall, their algorithmic skills are very good. To re-check the students' answers, add up the molar mass of the compound from the molecular formula obtained and compare it with the molar mass of vitamin C. If the results are the same, then the molecular formula obtained is correct.

Most of the students in the lower group did not understand the concept of empirical formulas and molecular formulas. Students cannot understand the problem well and do not understand the steps that must be planned to solve the problem. This is caused by the low understanding of students on the concept of elemental content in compounds and the concept of moles, so that the ability to solve problems is low. 


\section{h. Correlation of Polya Steps}

The correlation between students' scores on mastery of each step of Polya's problem-solving was high. Thus it can be seen that the four steps (understanding the problem, developing a settlement plan, implementing the plan, and re-examining) have a strong relationship. The correlation of mastery of Polya's steps in the upper group students showed a correlation number of 0.786 , the middle group was 0.883 , while the lower group had a correlation score of 0.803 . Based on the results of the correlation, it can be concluded that the higher the mastery of students in understanding the problem, the higher the ability to develop a plan of completion, as well as the mastery of the steps to implement the plan, students who understand and understand the steps used to solve problems can solve the problem. Well, at this step, algorithmic skills are also decisive in the success of solving problems. The last step is to re-examine; this step needs to be mastered to strengthen the steps taken previously. Inaccuracy often causes students to fail in solving problems in chemistry. Mastery of problem-solving steps for the upper group is very high. The average percentage of problem-solving abilities of upper group students based on the Polya model is $85 \%$. The problem-solving abilities for the middle group are high, indicated by an average percentage of $68 \%$, while problem-solving skills are high. Solving of the lower group is low, namely $36 \%$. The following is the average mastery of each step of the entire group.

\section{CONCLUSION}

Based on the research that has been done, the following conclusions can be drawn. Students' problem-solving ability in the upper group is very high, and the middle group is quite high. In contrast, the lower group is low mastery of Polya's steps, respectively $85 \%, 68 \%$, and $36 \%$. There is a significant correlation between students' mastery of problem-solving steps. The correlation of mastery of problemsolving steps of students in the upper group was 0.786 (high), the middle group was 0.883 (very high), and the lower group had a correlation score of 0.803 (very high).

\section{REFERENCES}

Amalia, F.R. 2015. Identifikasi Kesulitan Siswa Kelas XI MLA SMA Negeri 1 Kauman Tulungagung dalam Menyelesaikan Soal-soal Stoikiometri Menggunakan Analisis Langkah Penyelesaian Soal. Skripsi tidak diterbitkan. Malang: FMIPA Universitas Negeri Malang.

Bodner, George M. \& Herron, J. Dudley. 2002. Problem Solving in Chemistry. Chemical Education: Towards Research-based Practice Kluwer, 235-266

Bodner, George M. \& Domin, Daniels. 2000. Mental Models: The Role of Representations in Problem Solving in Chemistry. University Chemistry Education. 4: 24-30.

Chang, Raymond. 2005. Kimia Dasar: Konsep-Konsep Inti Jilid 1/ Edisi ketiga. Bandung: Erlangga

Chiu, M.H. 2001. Algorithmic Problem Solving and Conceptual Understanding of Chemistry by Student at a Local High School in Taiwan. Journal of Chemical Education International, 11(1): 20-38.

Chiu, M.H. 2005. A National Survey of Students' Conceptions in Chemistry in Taiwan. Chemical Education International, 6 (1): 1-8.

Effendy. 2006. A-Level Chemistry for Senior High Students Volume 2A. Malang: Bayumedia Publishing.

Gabel, Dorothy L., Sherwood, Robert D., \& Enochs, Larry. 1984. Problem-Solving Skills of High School Chemistry Students. Journal of Research in Science Teaching. 21 (2): 221-233

Hiebert, J. 1985. Conceptual and Procedural Knowledge: The Case of Mathematics. London: Lawrence Enibaum Associates.

Nurjannah, Fitria. 2014. Analisis Langkah-Langkah Dalam Menyelesaikan Masalah Perbitungsn Pada Materi Stokiometri Siswa Kelas X SMA Negeri 1 Situbondo. Skripsi tidak diterbitkan. Malang: FMIPA Universitas Negeri Malang.

Polya, G. 1957. How to solve it: a New Aspect of mathematical method. Princeton, USA: Princeton University Press Silberberg, Martin S. 2009. Chemistry The Molecular Nature of Matter Fifth Edition. New York: Mcgraw-hill Sugiyono, 2015. Memahami Penelitian Kualitatif. Bandung: Alfabeta. 
Profile of Polya's problem-solving abilities model among senior high school students: lesson from stoichiometric class

Zidny, Robby, Sopandi, Wahyu, Kusrijadi, Ali. 2013. Analisis Pemahaman Konsep Siswa SMA Kelas X pada Materi Persamaan Kimia dan Stoikiometri melalui Penggunaan Diagram Submikroskopik serta Hubungannya dengan Kemampuan Pemecaham Masalah. Jurnal Riset dan Praktik. Pendidikan Kimia. 1(1) 